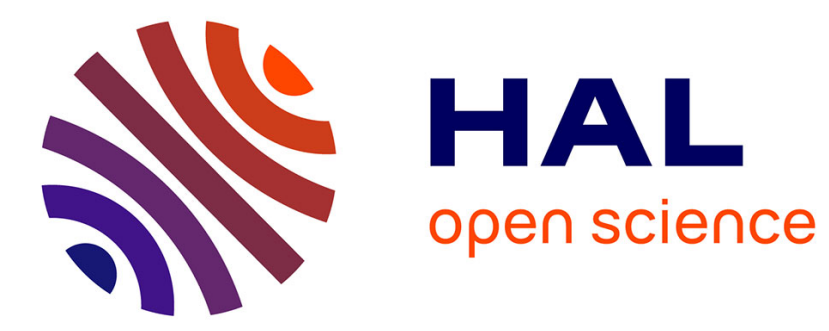

\title{
Surface properties evolution of attapulgite by IGC analysis as a function of thermal treatment
}

\author{
Lilya Boudriche, Rachel Calvet, Boualem Hamdi, Henri Balard
}

\section{To cite this version:}

Lilya Boudriche, Rachel Calvet, Boualem Hamdi, Henri Balard. Surface properties evolution of attapulgite by IGC analysis as a function of thermal treatment. Colloids and Surfaces A: Physicochemical and Engineering Aspects, 2012, 399, pp.1-10. 10.1016/j.colsurfa.2012.02.015 . hal-01688413

\section{HAL Id: hal-01688413 \\ https://hal.science/hal-01688413}

Submitted on 7 Nov 2018

HAL is a multi-disciplinary open access archive for the deposit and dissemination of scientific research documents, whether they are published or not. The documents may come from teaching and research institutions in France or abroad, or from public or private research centers.
L'archive ouverte pluridisciplinaire HAL, est destinée au dépôt et à la diffusion de documents scientifiques de niveau recherche, publiés ou non, émanant des établissements d'enseignement et de recherche français ou étrangers, des laboratoires publics ou privés. 


\title{
Surface properties evolution of attapulgite by IGC analysis as a function of thermal treatment
}

\author{
Lilya Boudriche $^{\mathrm{a}, \mathrm{b}, *}$, Rachel Calvet ${ }^{\mathrm{c}}$, Boualem Hamdi $^{\mathrm{b}}$, Henri Balard ${ }^{\mathrm{d}}$ \\ ${ }^{a}$ Centre de Recherche Scientifique et Technique en Analyses Physico-Chimiques (C.R.A.P.C), BP 248, Alger Rp, 16004 Alger, Algeria \\ ${ }^{\mathrm{b}}$ Lab. d'Etude Physico-Chimique des Matériaux et Application à l'Environnement, Fac. de Chimie, USTHB, BP 32 El Alia, Bab Ezzouar, 16111 Alger, Algeria \\ ${ }^{c}$ Université de Toulouse, Mines Albi, CNRS, Centre RAPSODEE, Campus Jarlard, F-81013 Albi Cedex 09, France \\ ${ }^{d}$ Lab. Chimie Physique, ENSISA-W, 11, rue Werner, 68093 Mulhouse Cedex, France
}

\begin{abstract}
A B S T R A C T
At low temperatures, thermal treatment of attapulgite clay causes a loss of mass due to the elimination of linked, zeolitic and crystallized water molecules. At high temperatures, there is a junction of particles until total melting of the attapulgite fibers. This transformation reduces significantly the volume of the porous network resulting in the drop in the value of specific surface area and causing important changes in the textural, structural and surface properties of the raw attapulgite. The inverse gas chromatography shows sensitivity of the attapulgite sample to the effect of temperature through the decrease of the dispersive component of the surface energy $\gamma_{s}^{d}$. The evolution of the nanomorphological index, a measurement of the surface nanorugosity, follows the appearance of surface roughness on carbonates with the increase of the temperature. The surface heterogeneity, determined by calculating the distribution functions of adsorption energies also underlines the morphology changes and the formation of new phases under the effect of temperature.
\end{abstract}

\section{Introduction}

Clays are used in various application areas such as ceramic, paper, paint, adsorbent, catalyst, etc. [1-3]. However, it is know that clay minerals are materials sensitive to thermal stress, and may undergo many changes with a consumption or release of energy with or without loss of mass. In this context, many studies were made to assess to the thermal transformations of some clays [4-9].

Our study investigates the changes, under temperature effect, of a fibrous clay from Algerian origin, called “attapulgite”. Although the dehydration and dehydroxylation of the attapulgite clays were studied in detail by thermogravimetric techniques [10-12], but there is no previous study on the evolution of surface properties of the solid after heat treatment. So, in this study, we focused on studying the evolution of surface properties of attapulgite by implementing a well-established analytical technique, the inverse gas chromatography [13-18] already used after acid treatment of the same solid [19]. It must be notice that only few studies by inverse gas chromatography were conducted on heat treated clays. We can

* Corresponding author at: Centre de Recherche Scientifique et Technique en Analyses Physico-Chimiques (C.R.A.P.C), BP 248, Alger Rp, 16004 Alger, Algeria. Tel.: +213 696521747; fax: +213 21247406.

E-mail addresses: boud_lil@yahoo.fr(L. Boudriche), calvet@mines-albi.fr (R. Calvet), bhamdi_99@yahoo.fr (B. Hamdi), h.balard@wanadoo.fr (H. Balard). quote the works of Brendle [20] who used IGC to follow the surface properties variations that occur when goethite transforms into hematite upon heat treatment.

Another study made by Hamdi [21] on a bentonite allows to note that the dispersive component of the surface energy $\left(\gamma_{s}^{d}\right)$ slightly increases for heat treatments less than $300^{\circ} \mathrm{C}$. The increase can be attributed to the elimination of the physically adsorbed water molecules and molecules present between lamellar sheets of the montmorillonite which let appear free active sites. Beyond $300^{\circ} \mathrm{C}$, the values of the $\gamma_{s}^{d}$ decrease significantly because the lamellar system of the montmorillonite is completely destroyed.

\section{Theoretical part}

Inverse gas chromatography (IGC) is an extension of conventional analytical gas chromatography. It permits, whatever the nature of the solid examined in the chromatographic column, to obtain information about its surface properties.

Depending on the amount of injected probe, the IGC can be divided into two modes: infinite dilution (IGC-ID) [22] and finite concentration (IGC-FC) [23,24].

\subsection{Inverse gas chromatography at infinite dilution (IGC-ID)}

The inverse gas chromatography at infinite dilution (IGC-ID) involves the injection of very small amounts of probe molecules 
(at the limit of detector sensitivity) in order to consider only the interactions between the solid-surface and an isolated probe. The IGC-ID gives different information according to the nature of the injected probe.

\subsubsection{The dispersive component of the surface energy $\left(\gamma_{s}^{d}\right)$}

This parameter indicates the ability of the solid surface to have non-specific interactions with probe molecules. Experimentally, the plot of the variation of the adsorption free energy versus the number of carbon atoms for an alkanes series leads to a straight line and from its slope is calculated the Gibbs energy adsorption of a methylene group $\Delta G_{a}^{\mathrm{CH}_{2}}$. The $\gamma_{s}^{d}$ is then calculated from the Dorris and Gray [25] relation:

$\gamma_{s}^{d}=\frac{\left(\Delta G_{a}^{\mathrm{CH}_{2}}\right)^{2}}{4 N^{2} a_{\mathrm{CH}_{2}}^{2} \gamma_{\mathrm{CH}_{2}}}$

where $\gamma_{s}^{d}$ the dispersive component of the surface energy $\left(\mathrm{mJ} / \mathrm{m}^{2}\right)$, $N$ the Avogadro's number, $a_{\mathrm{CH}_{2}}$ the molecular area of one methylene group $\left(0.06 \mathrm{~nm}^{2}\right), \gamma_{\mathrm{CH}_{2}}$ the surface energy of polyethylene $\left(\gamma_{\mathrm{CH}_{2}}=\right.$ $35.6+0.058(293-T))\left(\mathrm{mJ} / \mathrm{m}^{2}\right)$.

\subsubsection{The nanomorphological index $I_{M}\left(\chi_{t}\right)$}

Established by injecting branched or cyclic alkanes, this value delivers information about the regularity of the solid surface at the scale of the injected probe. Indeed, accessibility to the surface of a solid depends strongly on the probes encumbrances (cyclic and branched probe) and the surface roughness of the analyzed solid can be due to the existence of a porosity in the particles or to a superposition of two crystal planes which reveals structural defects giving to the surface a roughness at the nanoscale. The nanomorphology index $I_{M}\left(\chi_{t}\right)$ [22] for a branched or cyclic alkane is obtained by application of the following Eq. (2):

$I_{M}\left(\chi_{t}\right)=e^{-\Delta G_{a}^{M} / R T}$

where $-\Delta G_{a}^{M}$ is the departure of the representative point of the bulky alkane from the reference n-alkane straight line.

\subsubsection{The specific component of the surface energy $\left(I_{s p}\right)$}

Specific interactions include all types of interactions except the dispersive ones; they are obtained by injecting polar probes [22]. The difference between the global free energy of the injected polar probe and the straight line of alkanes probes represents the contribution of specific interactions $\Delta G_{a}^{s p}$ also noted $I_{s p}$ :

$\Delta G_{a}=\Delta G_{a}^{d}+\Delta G_{a}^{s p}$

It can be noticed that to calculate the $I_{M}\left(\chi_{t}\right)$ and the $I_{s p}$, the variation of the adsorption free energy is plot versus a topological index $\chi_{t}$ proposed by Brendlé [26] based on the Wiener index.

A limit of IGC-ID is reached for solids having a heterogeneous surface for which only the high energy sites mainly contribute to the retention times. So, IGC-FC can be carried out to overcome this limitation.

\subsection{Inverse gas chromatography at finite concentration (IGC-FC)}

In inverse gas chromatography at finite concentration (IGC-FC), some microliters of liquid probe are injected into the column containing the solid to be analyzed, in order to cover approximately with a probe mono-layer the surface of the solid. Then a strong asymmetric chromatographic peak is obtained when ideal, nonlinear conditions are fully fulfilled. Due to the presence of very energetic sites of adsorption, it is quite generally observed that a non-negligible part of the injected probe is not necessary eluted in time for the return of the signal to the initial base line. In order to assess this irreversibly adsorbed amount, the temperature of the chromatograph oven is increased up to the conditioning temperature, leading to appearance of a secondary small peak. Then irreversible part of the adsorption phenomena could be assessed from the ratio of the area of thermodesorption peak onto the total area of the chromatogram and have defined [13] an irreversibility index $\left(I_{\text {irr }}\right)$ according to Eq. (4):

$I_{i r r}=\frac{S_{t h}}{S_{r v}+S_{t h}}$

where $S_{r v}$ the surface of the main chromatographic peak and $S_{t h}$ the surface corresponding to the thermodesorption peak.

\subsubsection{The elution characteristic point method}

Applying "the elution characteristic point method" (ECP) to the reversible isothermal part of the experimental chromatogram, the desorption isotherm of the molecule probe can be obtained from a single chromatographic peak [23]. The first isotherm derivative is directly related to the net retention time of each point of diffuse front of the chromatogram by Eq. (5):

$$
\left(\frac{\partial N}{\partial P}\right)_{L, t_{r}}=\frac{D_{c}\left(t_{r}-t_{0}\right)}{m R T}
$$

where for a given characteristic point, $N$ is the number of adsorbed probe molecules, $P$ is the partial pressure of the probe at the output of the column - directly related to the height of the signal, $t_{r}$ is the retention time and $t_{0}$ the retention time of $\mathrm{CH}_{4}-\mathrm{a}$ molecule not retained by the solid surface, $D_{c}$ the corrected flow rate, $\mathrm{m}$ the mass of the solid contained in the column, $L$ the column length.

The integration of Eq. (5) gives access to the desorption isotherm which allows the determination of the Henry's and the BET constants, and of the specific surface area.

But the surface heterogeneity will influenced shape of the desorption isotherm. Intuitively, the residence times of the adsorbed molecules will depend of the energy of the adsorption site. Hence, the shape analysis of the isotherm will give access to the distribution function of the adsorption energies.

\subsubsection{Distribution function of the adsorption energies (DF)}

Estimation of the surface heterogeneity of a solid through the adsorption energy distribution function is generally based on a physical adsorption model which admits that the global isotherm may be considered as a sum of local isotherms of adsorption on isoenergetic domains (patchwork model).

Then, the distribution function of the relative abundance of each type of domain, having the same characteristic energy of interaction is given by the following integral Eq. (6):

$N\left(P_{m}, T_{m}\right)=N_{0} \int_{\varepsilon_{\min }}^{\varepsilon_{\max }} \theta\left(\varepsilon, P_{m}, T_{m}\right) \chi(\varepsilon) d \varepsilon$

where $N\left(P_{m}, T_{m}\right)$ is the number of molecules adsorbed at the pressure $P m$ and temperature $T m$ of measurement, $N O$ is the number of molecules needed for the formation of a monolayer, $\theta(\varepsilon, P m, T m)$ is the local isotherm, $\varepsilon$ is the adsorption energy of a site, and $\chi(\varepsilon)$ is the distribution function (DF) of the sites seen by the probe. The range of adsorption energies is included between minimal $\left(\varepsilon_{\min }\right)$ and maximal $\left(\varepsilon_{\max }\right)$ values. 


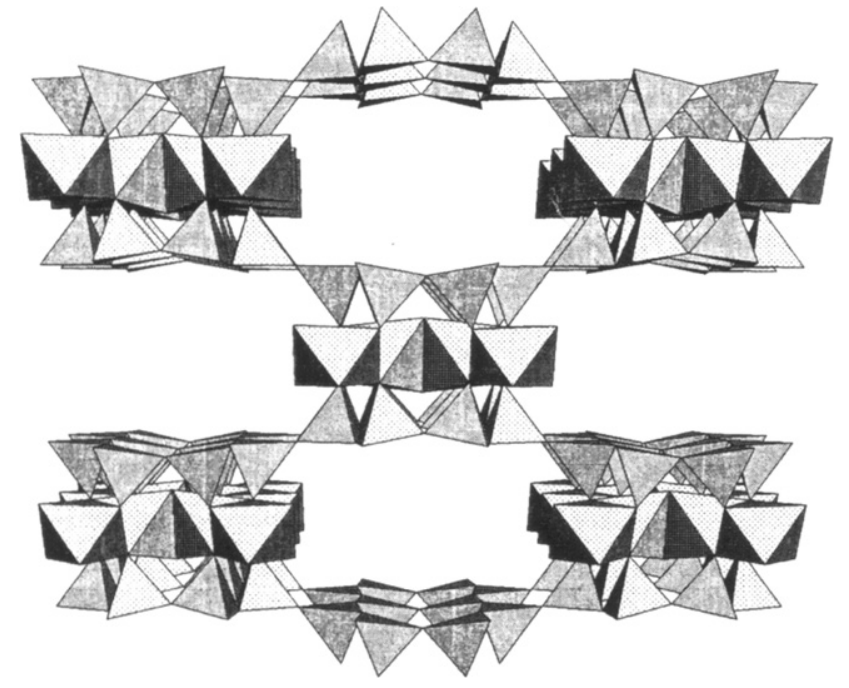

Fig. 1. Polyhedral representation of attapulgite [27].

The resolution of the integral Eq. (6) has been presented by Balard [24].

\section{Materials and methods}

\subsection{Material}

Attapulgite, or palygorskite, is a fibrous Mg-clay, which exhibits microchannels oriented longitudinally with the fibers (Fig. 1). The chemical composition of this clay mineral varies within certain limits according to its origin. The main variation is that an $\mathrm{A} 1^{3+}$ cation can replace $\mathrm{Mg}^{2+}$ in the octahedral sheet [12].

The natural attapulgite used in this study was obtained from the Ghoufi's region, located at the Northeast of Algeria. This clay has a fibrous morphology with presence of cubic inclusions attributed to carbonates [19]. The raw attapulgite was first coarsely milled and sieved to obtain a size fraction less than $1 \mathrm{~mm}$ allowing easier analysis, measurements, and treatments to be made in laboratoryscale processes.

\subsection{Thermal treatment of attapulgite}

The heat treatment of the clay was performed by means of a tubular furnace, controlled by a timer-controller type Eurotherm Controls, in a ceramic crucible. The heat treatment was realized in a temperature range from $100^{\circ} \mathrm{C}$ to $1000^{\circ} \mathrm{C}$ with a heating rate of $5^{\circ} \mathrm{C} /$ min under nitrogen rate flow. After each increase of $100^{\circ} \mathrm{C}$ in temperature, cooling is performed in an inert atmosphere.

Only temperatures leading to modifications in the solid properties are commented in this paper.

\subsection{Characterization methods}

Before IGC analysis, several complementary techniques were used to characterize our samples before and after heat treatment:

a. The thermogravimetric analysis (TGA) coupled with differential thermal analysis (DTA) provides information about the mass and enthalpy changes according to a heating rate. The coupling of these two techniques is often used to identify changes in the analyzed material. In our study, the device used was a TG-DTA SETARAM 92-16. Thermal analysis was done with a temperature rise of $5^{\circ} \mathrm{C} / \mathrm{min}$ from $30^{\circ} \mathrm{C}$ to $1000^{\circ} \mathrm{C}$. b. The dilatometric analysis provides access to dimensional changes of a sample as a function of temperature and time. The analysis was done by means of SETSYS-TMA 18 Setaram dilatometer, from $30^{\circ} \mathrm{C}$ to $1000^{\circ} \mathrm{C}$ with a ramp of $5^{\circ} \mathrm{C} / \mathrm{min}$.

c. The density of the obtained solids was determined by a helium pycnometer (Accupyc 1330-Micrometrics).

d. The specific surface areas, BET constants, meso and micro-pore volumes were determined using nitrogen adsorption at liquid nitrogen temperature (ASAP 2010, Micromeritics) by applying the BET, BJH, and $t$-plot methods, respectively. The samples were out gassed at $105^{\circ} \mathrm{C}$ for $24 \mathrm{~h}$ at a pressure of $6.6 \times 10^{-3}$ mbar.

e. The particle morphology was investigated using a scanning electron microscope (Philips XL 30 model ESEM-FEG) operating at $3 \mathrm{kV}$.

f. For the analysis of silicon, samples were mineralized by alkaline fusion with sodium hydroxide. For the analysis of the following elements: $\mathrm{Al}, \mathrm{Mg}, \mathrm{Ca}$, Fe, samples were mineralized by wet way in acid media. After mineralization, all the elements were then analyzed by ICP-AES.

g. Phase identification was performed on a Panalytical X'PERT Pro diffractometer (Philips) (CuK $\theta$ radiation) with a step size of $0.017^{\circ}$ for $2 \theta$ angles ranging from $5^{\circ}$ to $80^{\circ}$. The $2 \theta$ values were analyzed with the X'Pert High Score software and compared with the ICDD (International Centre for Diffraction Data) database.

h. The IR spectra of activated attapulgite were obtained using a Perkin Elmer 560 Fourier transform infrared (FTIR) spectrophotometer with a resolution of $2 \mathrm{~cm}^{-1}$ and a scan number equal to 64 . The spectral study was extended over the range $4000-400 \mathrm{~cm}^{-1}$. The analysis was done on $\mathrm{KBr}$ pellets with $1 \%$ of treated sample, using a hydraulic press by applying a pressure of $73.5 \mathrm{kPa}$.

The IGC measurements were performed with two GC devices (Agilent $7890 \mathrm{~A}$ and 6890), fitted with sensitive flame ionization detectors (FID). Helium was used as the carrier gas with a flow rate of $30 \mathrm{~mL} / \mathrm{min}$ measured with an electronic flowmeter (Flow500-Agilent). The temperatures of the injector and detector were respectively $130^{\circ} \mathrm{C}$ and $200^{\circ} \mathrm{C}$. The columns were filled with a mixture of attapulgite powder and glass beads so as to lower the pressure drop ( $<1$ bar) through the columns in order to avoid leaks at fittings.

The IGC-ID study was done with an oven temperature of $130^{\circ} \mathrm{C}$, using stainless steel columns of $20 \mathrm{~cm}$ in length, with $6.35 \mathrm{~mm}$ in internal diameter. The columns were conditioned overnight at $150^{\circ} \mathrm{C}$. The probes used were linear alkanes (hexane C6, heptane C7 and octane C8), a branched alkanes, the 2,3,4trimethylpentane (2,3,4-TMP) and 2,5-dimethylhexane (2,5-DMH), a cyclic alkane, the cycloctane (cycl8) and polar probes (chloroform and dichloromethane). These probes had a chromatographic grad (>99\%) purity.

For IGC-FC, the chromatographic columns were $10 \mathrm{~cm}$ in length with $6.35 \mathrm{~mm}$ or $3.18 \mathrm{~mm}$ in internal diameter. The conditioning temperature was $130^{\circ} \mathrm{C}$ and analysis temperature was depending on the probe used, according to the Conder criterion [23] which states that the contribution of probe vapor to the flow of carrier gas does not exceed $5 \%$ of the initial flow at the maximum of the chromatographic peak. Three probes were examined in IGC-FC, the octane (C8) at $53{ }^{\circ} \mathrm{C}$, the isopropanol (IP) at $43^{\circ} \mathrm{C}$ and the $1,4-$ dioxan (DX) at $51^{\circ} \mathrm{C}$. We chosed an apolar probe, octane, to study the surface morphology and two polar probes to study the surface chemistry. These probes had a chromatographic grade $(>99 \%)$ purity and were placed on a molecular sieve to avoid the water effect. The chromatograms were treated using a home-made software from the Adscientis Society (Wittelsheim, France). 


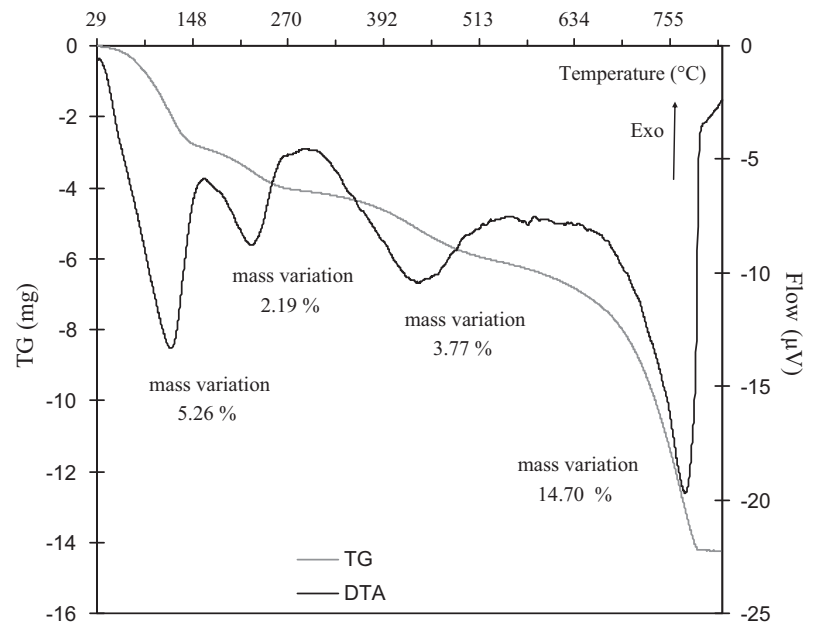

Fig. 2. TGA-DTA analysis of attapulgite.

\section{Results and discussion}

\subsection{Thermal analysis}

\subsubsection{TGA-DTA analysis}

TGA-DTA analysis (Fig. 2) indicates that attapulgite undergo four losses in mass of about $25.93 \%$ of the initial mass.

The losses in mass occur respectively in the following ranges: $30-160{ }^{\circ} \mathrm{C}(5.26 \%), 160-280^{\circ} \mathrm{C}(2.19 \%), 280-550{ }^{\circ} \mathrm{C}(3.77 \%)$ and $650-800{ }^{\circ} \mathrm{C}(14.70 \%)$. The first mass loss is quite quick, and corresponds to the removal of bound water (on the surface) and a part of the zeolitic water (located in the channels). The second water loss corresponds to the total elimination of the zeolitic water. Up to $280^{\circ} \mathrm{C}$, the phenomenon is perfectly reversible and the clay behaves as an excellent absorbent towards water. When the temperature increases, it causes between $280^{\circ} \mathrm{C}$ and $550^{\circ} \mathrm{C}$ a slow departure of crystallized water (coordinated to cations situated along octahedral sheets) with an evolution towards a rafter structure. It should be noted that an attapulgite in this state is still able to adsorb water by capillarity [28]. The fourth water mass loss is produced by dehydroxylation of $\mathrm{Mg}-\mathrm{OH}$ groups in attapulgite $[10,29]$. The elimination of water molecules at these temperatures is accompanied by a partial destruction of the crystal structure of attapulgite [30]. The release of the carbon hydroxide must be also considered in the fourth mass loss because beyond $500^{\circ} \mathrm{C}$; the carbonates present in the attapulgite are thermically unstable and their decomposition releases the $\mathrm{CO}_{2}$ [31].

Several authors studied the thermal analysis of this clay $[11,32,33]$ and they observed the mass losses at the same temperatures.

\subsubsection{Dilatometric analysis}

Three retractions (volume change) are observed from the dilatometric analysis (Fig. 3).

The first one occurs between $30^{\circ} \mathrm{C}$ and $200^{\circ} \mathrm{C}$, and is due to the evaporation of bounded and zeolitic water molecules, previously observed in TGA-DTA analysis (Fig. 2). It is very low, $0.6 \%$ of the initial height $(1.75 \mathrm{~mm})$. The second retraction, a little higher than the first one, $2.8 \%$, happens between $200^{\circ} \mathrm{C}$ and $400^{\circ} \mathrm{C}$, it can be attributed to the evaporation of crystallized water out of the structure of attapulgite. The highest volume change takes place between $750^{\circ} \mathrm{C}$ and $900^{\circ} \mathrm{C}$, corresponding in TGA-DTA curve to a mass loss of $14.7 \%$. In this case, there is a densification of the material and the shrinkage is estimated of about $437.55 \mu \mathrm{m}$ in the measuring cell, representing $24 \%$ of the initial height.

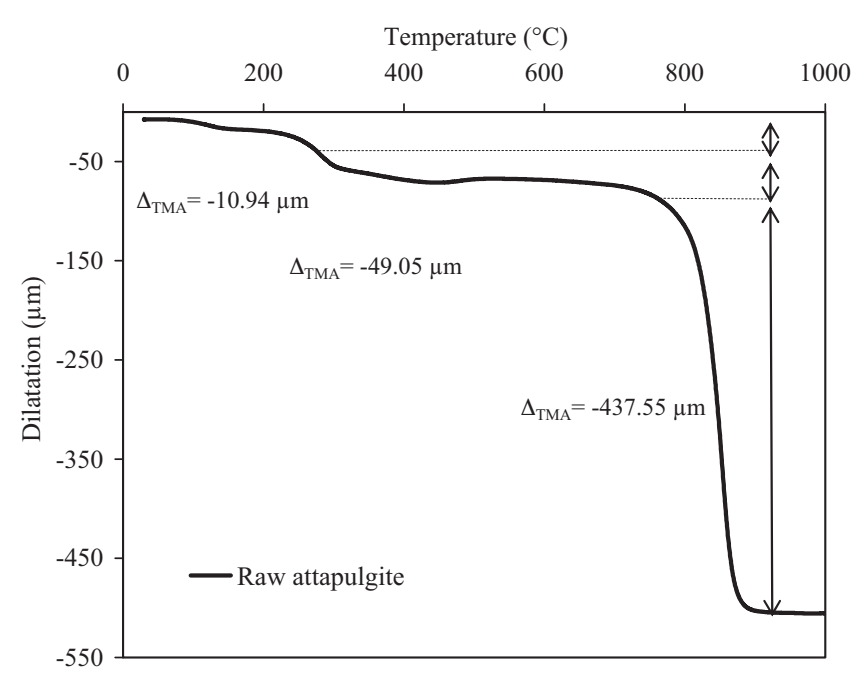

Fig. 3. Dilatometric analysis of attapulgite (initial height: $1.75 \mathrm{~mm}$ ).

Table 1

Density values of attapulgite before and after heat treatment, measured by helium pycnometer.

\begin{tabular}{ll}
\hline Samples & Average density $\left(\mathrm{g} / \mathrm{cm}^{3}\right)$ \\
\hline Raw attapulgite & 2.57 \\
$200^{\circ} \mathrm{C}$ & 2.65 \\
$400^{\circ} \mathrm{C}$ & 2.77 \\
$800^{\circ} \mathrm{C}$ & 2.97 \\
$1000^{\circ} \mathrm{C}$ & 3.04 \\
\hline
\end{tabular}

This consolidation of attapulgite particles under the effect of heating is called sintering $[34,35]$. The consolidation of a material could be emphasized using a helium pycnometer.

\subsection{Textural analysis}

\subsubsection{Density measurement by helium pycnometer}

The values of average densities confirm the sintering of the attapulgite under the effect of the increase of the heat temperature (Table 1 ). The density equal to 2.574 for the raw material increases gradually to 3.038 after the heating to $1000^{\circ} \mathrm{C}$.

Another characteristic of the material that will certainly be affected by the sintering is the surface morphology in terms of specific surface areas and porosity measured by nitrogen adsorption at $77 \mathrm{~K}$.

\subsubsection{Surface analysis by nitrogen adsorption}

Table 2 contains the specific surface areas, BET constants, meso and micro-porous volumes obtained from nitrogen adsorption isotherms under heat treatment effect.

The texture of attapulgite evolves significantly during the heat treatment. The specific surface area decreases as the temperature increases up to $2 \mathrm{~m}^{2} / \mathrm{g}$ at $1000^{\circ} \mathrm{C}$. It is linked to the disappearance of the micropores since $200^{\circ} \mathrm{C}$ while the mesopores only

Table 2

Values of specific surface areas $\left(a_{\mathrm{BET}}\right)$, BET constants $\left(C_{\mathrm{BET}}\right)$, volumes of micro- and meso-pores attapulgite samples heat treated at $200^{\circ} \mathrm{C}, 400^{\circ} \mathrm{C}, 800^{\circ} \mathrm{C}$ and $1000^{\circ} \mathrm{C}$.

\begin{tabular}{crrll}
\hline & $\begin{array}{l}a_{\mathrm{BET}} \\
\left(\mathrm{m}^{2} / \mathrm{g}\right)\end{array}$ & $C_{\mathrm{BET}}$ & $\begin{array}{l}V_{\text {meso }} \\
\left(\mathrm{cm}^{3} / \mathrm{g}\right)\end{array}$ & $\begin{array}{l}V_{\text {micro }} \\
\left(\mathrm{cm}^{3} / \mathrm{g}\right)\end{array}$ \\
\hline Raw attapulgite & 125.1 & 436 & 0.302 & 0.018 \\
$200^{\circ} \mathrm{C}$ & 88.3 & 170 & 0.271 & 0.007 \\
$400^{\circ} \mathrm{C}$ & 81.5 & 173 & 0.340 & 0.006 \\
$800^{\circ} \mathrm{C}$ & 28.6 & 176 & 0.256 & - \\
$1000^{\circ} \mathrm{C}$ & 1.6 & 28 & - & - \\
\hline
\end{tabular}



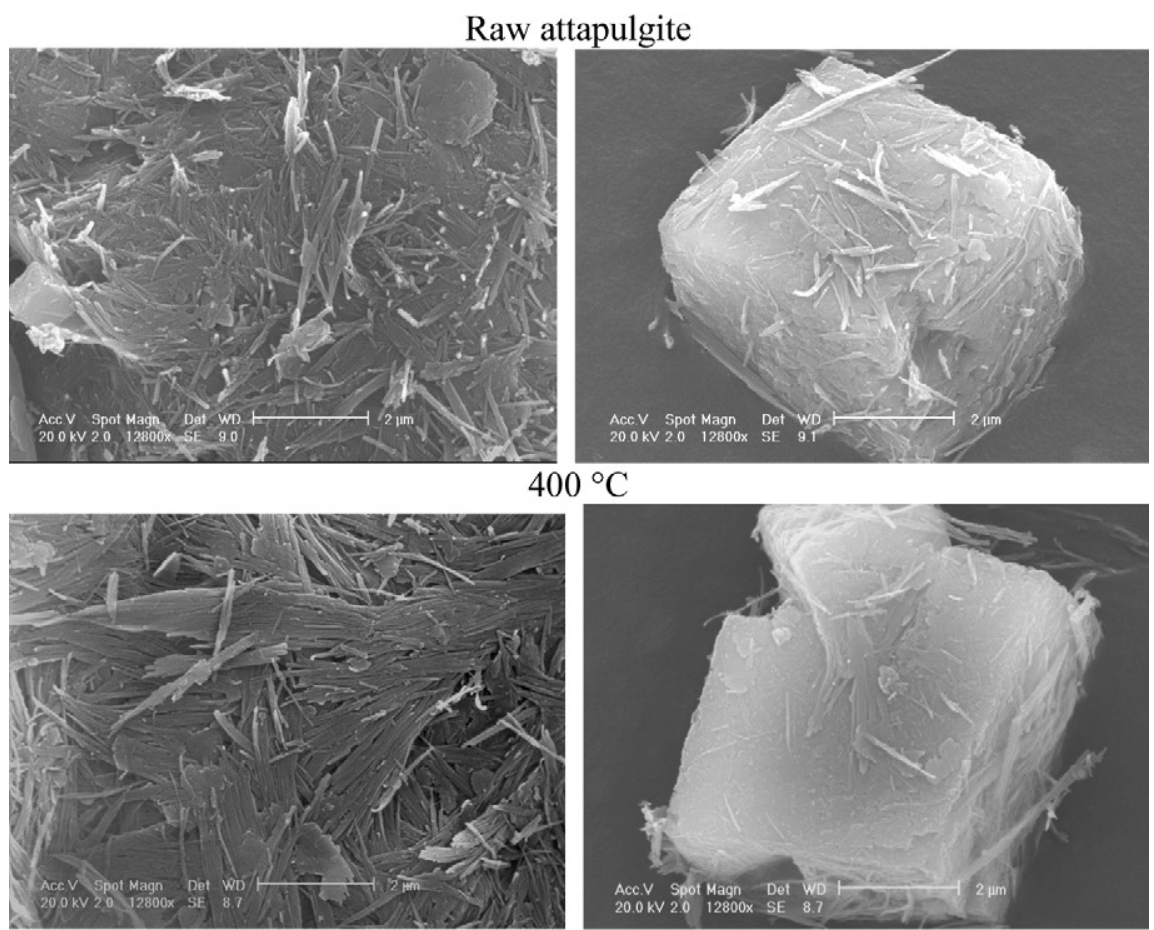

$800^{\circ} \mathrm{C}$
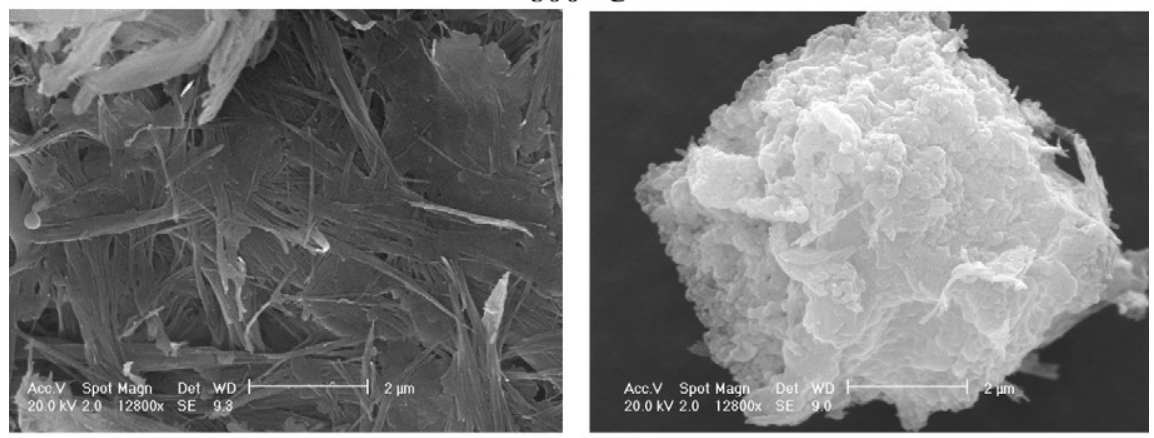

$1000^{\circ} \mathrm{C}$
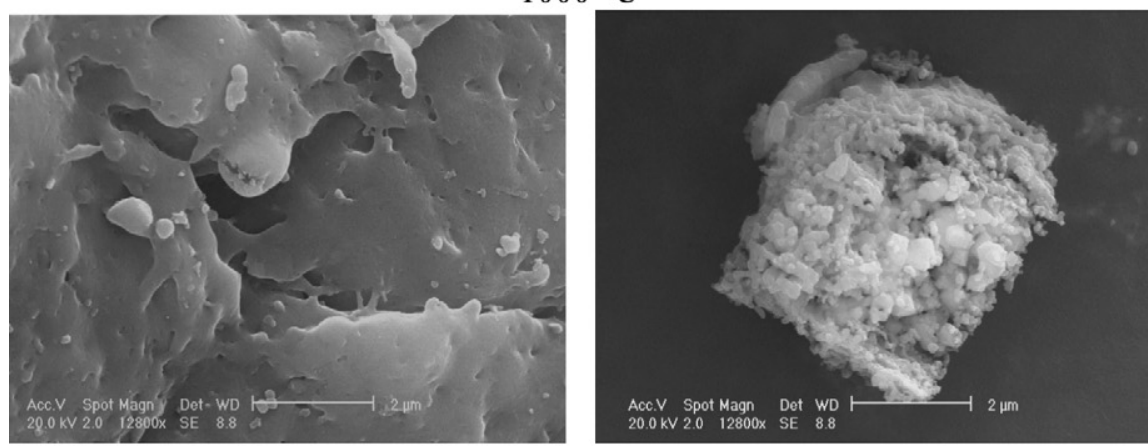

Fig. 4. Micrographs of attapulgite before and after calcination at $400^{\circ} \mathrm{C}, 800^{\circ} \mathrm{C}$ and $1000^{\circ} \mathrm{C}$.

disappear at $1000^{\circ} \mathrm{C}$. A similar change was obtained for attapulgite from India [36] since its initial surface area decreases from $186 \mathrm{~m}^{2} / \mathrm{g}$ to $140 \mathrm{~m}^{2} / \mathrm{g}$ at $200^{\circ} \mathrm{C}$, it decreased further at $350^{\circ} \mathrm{C}$ to $123 \mathrm{~m}^{2} / \mathrm{g}$, and at $500^{\circ} \mathrm{C}$ it reached $129 \mathrm{~m}^{2} / \mathrm{g}$. Sidheswaran [36] attributed the decrease in surface area at high temperatures to the formation of two crystalline phases: forsterite $\left(\mathrm{MgSiO}_{4}\right)$ and enstatite $\left(\mathrm{MgSiO}_{3}\right)$.

Another study [37] on attapulgite from Tunisia, led to different results. Indeed, the specific surface area of the attapulgite initially equal to $67.4 \mathrm{~m}^{2} / \mathrm{g}$ increased successively, to $74.2 \mathrm{~m}^{2} / \mathrm{g}$ at $350^{\circ} \mathrm{C}$, then, to $85.9 \mathrm{~m}^{2} / \mathrm{g}$ at $550^{\circ} \mathrm{C}$, before decreasing to $60.7 \mathrm{~m}^{2} / \mathrm{g}$ at $750{ }^{\circ} \mathrm{C}$. The increase in the observed surface was attributed to the elimination of water molecules, leading to the appearance of a new porosity while the decrease of the surface was interpreted by the coalescence of particles under the effect of temperature.

In this study, the continues decreasing in the surface area, whatever the heat treatment temperature, can be linked to the disappearance of the porous volume, more exactly the microporous volume, caused by the coalescence of particles from $200^{\circ} \mathrm{C}$. It can be supposed reasonably that the ability to observe the departure of water from the measurement of specific surface area depends on the degassing conditions.

Then, it was interesting to observe by scanning electron microscopy the effect of the heat treatment on the morphology of attapulgite. 
Table 3

Chemical composition analysis of raw and heat-treated attapulgite at $400^{\circ} \mathrm{C}, 800^{\circ} \mathrm{C}$ and $1000^{\circ} \mathrm{C}$.

\begin{tabular}{llccc}
\hline Element (\%) & \multicolumn{4}{l}{ Elemental analysis } \\
\cline { 2 - 5 } & Raw attapulgite & $400{ }^{\circ} \mathrm{C}$ & $800^{\circ} \mathrm{C}$ & $1000^{\circ} \mathrm{C}$ \\
\hline $\mathrm{Si}$ & 16.63 & 20.21 & 22.89 & 25.93 \\
$\mathrm{Mg}$ & 6.35 & 7.01 & 7.98 & 8.53 \\
$\mathrm{Al}$ & 4.12 & 5.05 & 5.8 & 6.28 \\
$\mathrm{Ca}$ & 8.62 & 4.84 & 5.74 & 5.90 \\
$\mathrm{Fe}$ & 2.33 & 2.72 & 3.15 & 3.40 \\
$\mathrm{C}$ & 5.03 & 2.41 & 0.44 & $<0.30$ \\
\hline
\end{tabular}

\subsection{Morphological analysis by SEM}

The SEM micrographies (Fig. 4) represent the morphological evolution of attapulgite fibers and carbonates before and after heat treatment at $400^{\circ} \mathrm{C}, 800^{\circ} \mathrm{C}$ and $1000^{\circ} \mathrm{C}$.

At $400^{\circ} \mathrm{C}$, SEM analysis indicates that the fibers and carbonates are still preserved. From $800^{\circ} \mathrm{C}$, there is an alteration of carbonates which appear roughness, contrary to the initial state. At the same temperature, some attapulgite fibers appear slightly affected because they melt. A total disappearance of the fibrous morphology happens at $1000^{\circ} \mathrm{C}$, because of their complete fusion while the carbonates inclusions have distinctly granular appearance.

\subsection{Chemical structure}

\subsubsection{Determination of chemical composition by elemental} analysis

Cations present in the attapulgite sample before and after heat treatment at $400^{\circ} \mathrm{C}, 800^{\circ} \mathrm{C}$ and $1000^{\circ} \mathrm{C}$ were determined by elemental analysis (Table 3).

The decrease in the carbon percentage with the temperature increasing is caused by the release of carbon oxides, indeed, at $500{ }^{\circ} \mathrm{C}$, calcite $\left(\mathrm{CaCO}_{3}\right)$ and dolomite $\mathrm{CaMg}\left(\mathrm{CO}_{3}\right)_{2}$ are thermally unstable and decompose respectively into $\mathrm{CaO}, \mathrm{CO}_{2}$ and $\mathrm{MgO}$, $\mathrm{CaCO}_{3}, \mathrm{CO}_{2}$. Similar results were obtained by Hamdi [31] during calcination of a diatomite containing calcite, at the same temperature. In addition to the decomposition of carbonates, the decomposition of organic carbon must be considered in the clay matrix. Other elements ratios increase as the consequence of the carbon ratio decrease. Indeed, it is very difficult to induce dealuminization at temperatures below $800^{\circ} \mathrm{C}$, so the presence of aluminum, either in free form $\left(\mathrm{Al}_{2} \mathrm{O}_{3}\right)$ or combined with silica (aluminosilicate), displays a thermal stability $[38,39]$. On the other hand, the ferric species are stable beyond $800^{\circ} \mathrm{C}$.

In order to confirm the decomposition of carbonates, X-ray diffraction analysis was made on samples.

\subsubsection{Mineralogical analysis by X-ray diffraction}

Fig. 5 shows the diffraction patterns of raw and calcined attapulgite at $400^{\circ} \mathrm{C}, 800^{\circ} \mathrm{C}$ and $1000^{\circ} \mathrm{C}$.

At $400^{\circ} \mathrm{C}$, the disappearance and the decrease in the intensity of some peaks reflect a decrease in the solid crystallinity. However, attapulgite and carbonates, like dolomite $\mathrm{CaMg}\left(\mathrm{CO}_{3}\right)_{2}$ and calcite $\mathrm{CaCO}_{3}$ seem to be resistant to heating at $400^{\circ} \mathrm{C}$. At $800^{\circ} \mathrm{C}$, the amorphization is complete, and at this temperature the crystal structure of attapulgite is entirely destroyed with the disappearance of attapulgite and carbonates and appearance of iron oxide and quartz.

At $1000^{\circ} \mathrm{C}$, new peaks located at $28(2 \theta), 30(2 \theta), 31(2 \theta), 36(2 \theta)$, $45(2 \theta), 52(2 \theta)$ and $57(2 \theta)$ are related to the formation of new crystalline phases such as the augite $\mathrm{Ca}(\mathrm{Fe}, \mathrm{Mg}) \mathrm{Si}_{2} \mathrm{O}_{6}$ and the forsterite $\mathrm{MgSiO}_{4}$. These phases are formed following the topotactic transformations.

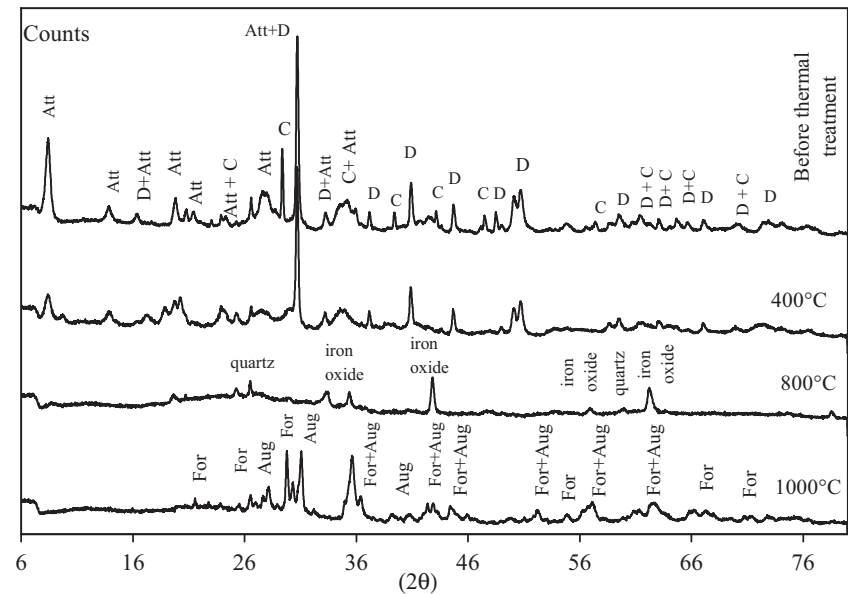

Fig. 5. Attapulgite diffraction patterns before and after heat treatments at $400^{\circ} \mathrm{C}, 800^{\circ} \mathrm{C}$ and $1000^{\circ} \mathrm{C}($ Att $=$ attapulgite, $\mathrm{D}=$ dolomite, $\mathrm{C}=$ calcite, For $=$ forsterite, Aug = augite)

A study of different hydration states of sepiolite [28] showed that the major disorganization in the structure occurs with the departure of crystallized water (at about $500{ }^{\circ} \mathrm{C}$ ) and results in a phase where the elements are rotated as illustrated in Fig. 6.

At high temperature, the sepiolite reaches the dehydroxylation stage and this transformation is achieved at around $850-875^{\circ} \mathrm{C}$, corresponding to a total reorganization of the cell with the formation of enstatite.

In our study, when the temperature increases, the color of the raw attapulgite changes from light brown to brick red at $900{ }^{\circ} \mathrm{C}$. This color change means that isomorphous substitutions by iron can occurs within the structure $\left(\mathrm{Si}^{4+}\right.$ can be replaced by $\mathrm{Fe}^{3+}$ and $\mathrm{Mg}^{2+}$ by $\mathrm{Fe}^{2+}$ ), which gradually makes the treated surface composed essentially of iron oxide (Fig. 5). The powder calcined at $1000^{\circ} \mathrm{C}$ is gray, this can be attributed to a complete elimination of organic matter, as was demonstrated for a kaolinite of Brazil [4], calcined at $550^{\circ} \mathrm{C}$ during 8 hours. This removal of organic matter was accompanied by a color change from dark brown before treatment to light gray.

In summary, the XRD analysis of heat treated samples indicates that attapulgite is undergoing profound changes, at temperatures above $400^{\circ} \mathrm{C}$.

The Fourier Transform Infrared Spectroscopy is also of interest to bring information on the evolution of the chemical functionality.

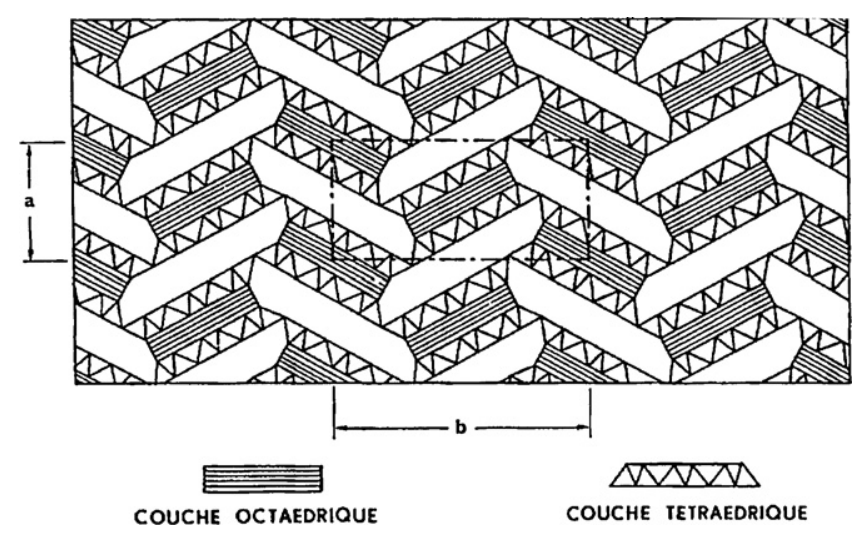

Fig. 6. Schematic structure of anhydrous sepiolite showing the rotation of the elements of the sheets relative to each other [28]. 


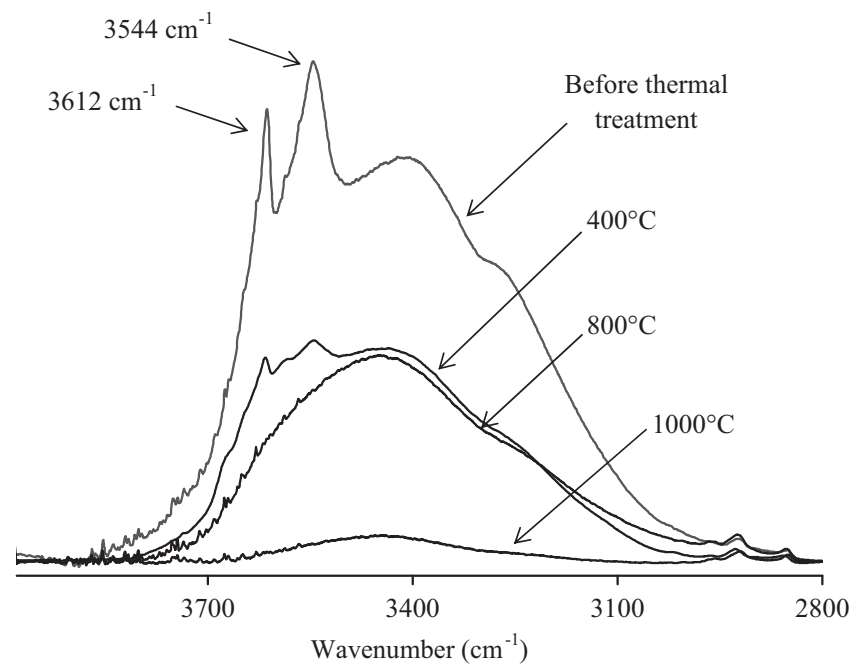

Fig. 7. FTIR spectra in absorbance units of attapulgite before and after heat treatment at $400^{\circ} \mathrm{C}, 800^{\circ} \mathrm{C}$ and $1000^{\circ} \mathrm{C}$, in the $3800-2900 \mathrm{~cm}^{-1}$ region.

\subsubsection{Determination of chemical functions by Fourier transform infrared spectroscopy (FTIR)}

Fig. 7 represents the spectra of FTIR of attapulgite heated at $400^{\circ} \mathrm{C}, 800^{\circ} \mathrm{C}$ and $1000^{\circ} \mathrm{C}$, in the region $3800-2900 \mathrm{~cm}^{-1}$.

FTIR analysis supports the elimination of water molecules. In details:

The hydroxyl vibrational bands at $3612 \mathrm{~cm}^{-1}$ and $3544 \mathrm{~cm}^{-1}$ (Fig. 7) decrease in intensity until it disappears completely at $800^{\circ} \mathrm{C}$, forming a broad band centered at $3450 \mathrm{~cm}^{-1}$. The first one is attributed to the contribution of stretching vibrations of $\mathrm{OH}$ in (Fe, Mg)-OH and ( $\mathrm{Al}, \mathrm{Mg}$ )-OH and the second one to the stretching vibration of $\mathrm{OH}$ associated with $\mathrm{Al}^{3+}$ cations in dioctahedral coordination $\mathrm{Al}_{2} \mathrm{OH}$ and $\mathrm{OH}$ stretching vibration of water coordinated with $\mathrm{Mg}$ along the fibers [40]. This evolution confirms the elimination of water molecules (linked, and zeolitic crystallized) and the dehydroxylation of $\mathrm{Mg}-\mathrm{OH}$ groups occurring at high temperatures.

Fig. 8 represents the spectra of FTIR attapulgite heated at $400^{\circ} \mathrm{C}$, $800^{\circ} \mathrm{C}$ and $1000^{\circ} \mathrm{C}$, in the region $1500-400 \mathrm{~cm}^{-1}$.

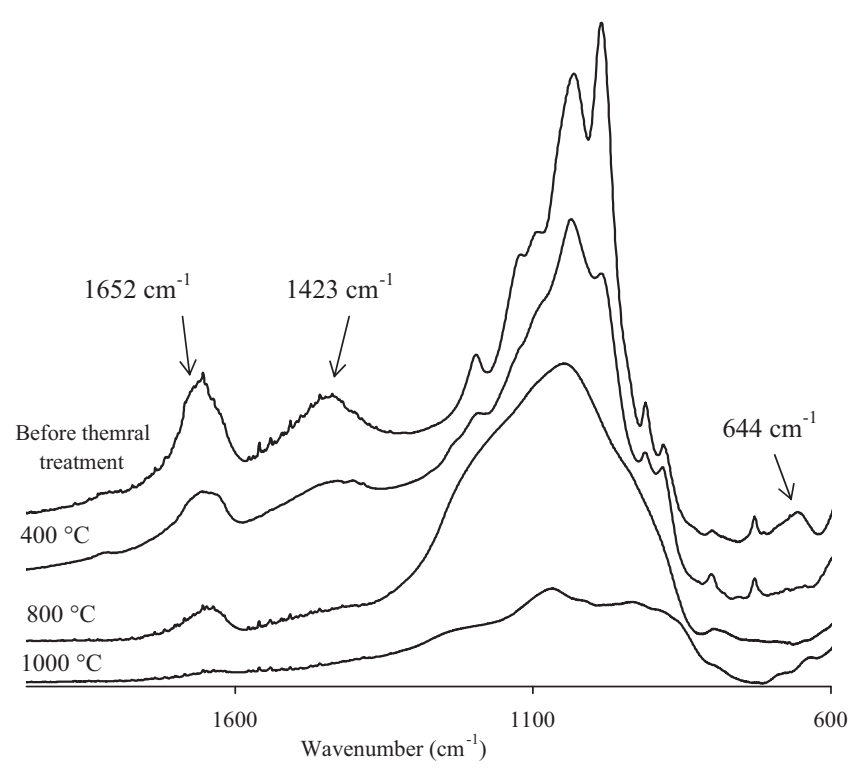

Fig. 8. FTIR spectra in absorbance units of attapulgite before and after heat treatment at $400{ }^{\circ} \mathrm{C}, 800^{\circ} \mathrm{C}$ and $1000^{\circ} \mathrm{C}$, in the $1500-400 \mathrm{~cm}^{-1}$ region.
In the region of low wavenumbers (Fig. 8), the band at $1652 \mathrm{~cm}^{-1}$ corresponding to the bending vibrations of $\mathrm{H}_{2} \mathrm{O}$ [41] also disappears when the temperature increases.

The band at $1423 \mathrm{~cm}^{-1}$, characteristic of carbonates [42], also decreases in intensity as the temperature increases, due to the thermal instability of carbonates.

The bands between $1200 \mathrm{~cm}^{-1}$ and $900 \mathrm{~cm}^{-1}$ for $\mathrm{Si}-\mathrm{O}$ vibration $[41,43]$ decrease in intensity until they disappear at $800^{\circ} \mathrm{C}$ revealing a broad band centered at $1030 \mathrm{~cm}^{-1}$. This variation reflects the partial destruction of the crystal structure of attapulgite from $800^{\circ} \mathrm{C}$ also observed by XRD.

The IR spectrum obtained at $1000^{\circ} \mathrm{C}$ reveals no new absorption peaks.

After reviewing the textural, structural and morphological properties evolution of the attapulgite under heat treatment, we focused on the inverse gas chromatography, a technique to follow the modifications of surface properties. The same samples have been examined by IGC at infinite dilution or finite concentration.

\subsection{Determination of surface properties by inverse gas chromatography}

\subsubsection{Inverse gas chromatography at infinite dilution (IGC-ID)}

Parameters like the dispersive component of the surface energy, $\gamma_{s}^{d}$, the nanomorphological index, $I_{M}\left(\chi_{t}\right)$, and the specific component of the surface energy, $I_{s p}$, obtained by IGC-ID at $130^{\circ} \mathrm{C}$, on attapulgite samples before and after thermal treatment are gathered in Table 4.

The dispersive component of the surface energy decreases when the temperature increases from $164 \mathrm{~mJ} / \mathrm{m}^{2}$ before treatment to $119 \mathrm{~mJ} / \mathrm{m}^{2}$ at $800^{\circ} \mathrm{C}$. This drop is attributed to the disappearance of structural defects in which the alkanes probes can establish strong dispersive interactions with the solid surface by insertion.

However, despite the disappearance of the porosity and structural defects measured respectively by nitrogen adsorption (Table 2) and by the $\gamma_{s}^{d}$ values (Table 4), the nanomorphological indexes $I_{M}\left(\chi_{t}\right)$ obtained with branched or cyclic probes decrease with increasing temperature, indicating the appearance of a roughness surface. Then, the evolution of the $I_{M}\left(\chi_{t}\right)$ can be attributed to the morphology of the carbonates, as observed by SEM analysis (Fig. 4), which becomes gradually roughness at high temperature.

The specific component of surface energy is not affected by thermal treatment meaning that the surface chemistry remains preserved.

\subsubsection{Inverse gas chromatography at finite concentration (IGC-FC)}

4.5.2.1. Study of desorption isotherms. In Table 5 are reported the values of specific surface areas values measured by nitrogen at $77 \mathrm{~K}$ and those obtained by IGC-FC, using: octane, isopropanol and dioxan probes. The irreversibility indexes of the same samples are also reported.

Whatever the probe used, the surface area decreases significantly under the effect of the temperature reaching values between 20 and $30 \mathrm{~m}^{2} / \mathrm{g}$ at $800^{\circ} \mathrm{C}$, depending of the injected probe. This is explained by the coalescence of particles occurring at high temperatures and which removes the roughness and surface porosity.

Before and after thermal treatment at $400^{\circ} \mathrm{C}$, specific surface area values with nitrogen are higher than those measured with organic probes. It was attributed to the approximation in the calculation of molecular areas of organic probes which are established from adsorption isotherms, generally, on nonporous solids. At $800^{\circ} \mathrm{C}$, the disappearance of the porosity and surface roughness under the thermal effect, makes the uncertainty in the calculation of molecular areas weak, because the surfaces are 
Table 4

Variations of the $\gamma_{s}^{d}, I_{M}\left(\chi_{t}\right)$ and $I_{s p}$ values of attapulgite samples, before and after thermal treatment at $400^{\circ} \mathrm{C}$ and $800^{\circ} \mathrm{C}$, obtained at an oven temperature of $130{ }^{\circ} \mathrm{C}$.

\begin{tabular}{|c|c|c|c|c|c|c|}
\hline & \multirow{2}{*}{$\begin{array}{l}\gamma_{s}^{d}\left(\mathrm{~mJ} / \mathrm{m}^{2}\right) \pm 4 \% \\
\mathrm{C} 6, \mathrm{C} 7, \mathrm{C} 8\end{array}$} & \multicolumn{3}{|l|}{$I_{M}\left(\chi_{t}\right) \pm 5 \%$} & \multicolumn{2}{|c|}{$I_{s p}(\mathrm{~kJ} / \mathrm{mol}) \pm 4 \%$} \\
\hline & & 2,3,4-TMP & 2,5-DMH & Cycl 8 & $\mathrm{CH}_{2} \mathrm{Cl}_{2}$ & $\mathrm{CHCl}_{3}$ \\
\hline Raw attapulgite & 164 & 0.69 & 0.67 & 0.22 & 17 & 14 \\
\hline \multicolumn{7}{|c|}{ After thermal treatment } \\
\hline $400^{\circ} \mathrm{C}$ & 143 & 0.68 & 0.61 & 0.24 & 16 & 13 \\
\hline $800^{\circ} \mathrm{C}$ & 119 & 0.43 & 0.34 & 0.18 & 18 & 13 \\
\hline
\end{tabular}

Table 5

Values of the specific surface areas ( $\left.a_{\mathrm{BET}}\right)$ and irreversibility indexes $\left(I_{\text {irr }}\right)$ of raw and thermal treated attapulgite, obtained by nitrogen adsorption and IGC-FC.

\begin{tabular}{|c|c|c|c|c|c|c|c|}
\hline & \multirow{3}{*}{$\begin{array}{l}\text { Adsorption } \mathrm{N}_{2} \\
a_{\mathrm{BET}}\left(\mathrm{m}^{2} / \mathrm{g}\right)\end{array}$} & \multicolumn{6}{|l|}{ IGC-FC } \\
\hline & & \multicolumn{2}{|l|}{$\mathrm{C} 8\left(53^{\circ} \mathrm{C}\right)$} & \multicolumn{2}{|l|}{$\operatorname{IP}\left(43^{\circ} \mathrm{C}\right)$} & \multicolumn{2}{|l|}{$\mathrm{DX}\left(51^{\circ} \mathrm{C}\right)$} \\
\hline & & $\overline{a_{\mathrm{BET}} \pm 2.8\left(\mathrm{~m}^{2} / \mathrm{g}\right)}$ & $I_{\text {irr }} \pm 0.2(\%)$ & $\overline{a_{\mathrm{BET}} \pm 4.5\left(\mathrm{~m}^{2} / \mathrm{g}\right)}$ & $I_{\text {irr }} \pm 0.6(\%)$ & $\overline{a_{\mathrm{BET}} \pm 3.6\left(\mathrm{~m}^{2} / \mathrm{g}\right)}$ & $I_{\mathrm{irr}} \pm 0.1(\%)$ \\
\hline Raw attapulgite & 125.1 & 114.5 & 0.6 & 70.9 & 8.3 & 71.0 & 7.8 \\
\hline \multicolumn{8}{|c|}{ After thermal treatment } \\
\hline $400^{\circ} \mathrm{C}$ & 84.4 & 81.7 & 1.2 & 67.1 & 12.8 & 61.1 & 9.3 \\
\hline $800^{\circ} \mathrm{C}$ & 28.6 & 29.9 & 5.3 & 21.8 & 18.7 & 25.1 & 12.8 \\
\hline
\end{tabular}

almost flat, leading to practically identical surface areas whatever the nature of the probe, this tends to prove that it is the positioning of the organic probes on the surface of solid which is the reason of differences observed for the samples treated at $400^{\circ} \mathrm{C}$.

Another explanation for the difference between the surfaces with nitrogen and those measured by IGC-FC, may be the amount of the irreversible adsorption which is not taken into account in IGCFC for the calculation of specific surfaces areas. The irreversibility indexes were used to quantify the irreversible adsorption, which increases with increasing the temperature of thermal treatment, indicating a greater affinity of these probes to the surface of the heated attapulgite. Taking into account the irreversible adsorption, corrected specific surface areas measured with the organic probes before and after treatment at $400^{\circ} \mathrm{C}$ (Table 6) are again lower than with nitrogen. Irreversible adsorption is not the only factor responsible of the low values of the specific surface areas measured with organic probes but also the uncertainty on the actual molecular area of the probes.

4.5.2.2. Assessment of the surface energetic heterogeneity. The heterogeneity of surface energy of attapulgite samples before and after thermal treatment was estimated by IGC at finite concentration

\section{Table 6}

Corrected values of specific surface areas $\left(a_{\text {corr }}\right)$ attapulgite samples before and after thermal treatment compared to those measured with nitrogen.

\begin{tabular}{|c|c|c|c|c|}
\hline & \multirow{2}{*}{$\begin{array}{l}a_{\mathrm{BET}}\left(\mathrm{m}^{2} / \mathrm{g}\right) \\
\mathrm{N}_{2}\end{array}$} & \multicolumn{3}{|c|}{$a_{\text {corr }}\left(\mathrm{m}^{2} / \mathrm{g}\right)$} \\
\hline & & $\mathrm{C} 8\left(53^{\circ} \mathrm{C}\right)$ & $\operatorname{IP}\left(43^{\circ} \mathrm{C}\right)$ & $\mathrm{DX}\left(51^{\circ} \mathrm{C}\right)$ \\
\hline $\begin{array}{l}\text { Raw attapulgite } \\
\text { After heat treatment }\end{array}$ & 125.1 & 115.2 & 76.9 & 76.5 \\
\hline \multicolumn{5}{|l|}{ After heat treatment } \\
\hline $400^{\circ} \mathrm{C}$ & 84.4 & 82.7 & 75.6 & 66.7 \\
\hline $800^{\circ} \mathrm{C}$ & 28.6 & 31.5 & 26.1 & 28.2 \\
\hline
\end{tabular}

conditions, choosing three probes with different polarities. The surface heterogeneity was evaluated by determining the adsorption energy distribution functions of the three probes according to the method of Rudzinski and Jagiello, by applying the technique of multiple derivations developed by Balard [24].

So, Fig. 9 shows the adsorption energy distribution functions of n-octane (a) isopropanol (b) and 1,4-dioxan (c) on the surface of attapulgite before and after thermal treatment at $400^{\circ} \mathrm{C}$ and $800^{\circ} \mathrm{C}$.

At $400^{\circ} \mathrm{C}$, the distribution functions with the three probes remain preserved comparatively to those of the raw attapulgite, on the contrary the distribution function (FD) of the sample treated at $800^{\circ} \mathrm{C}$ show the appearance of two shoulders at high energies,
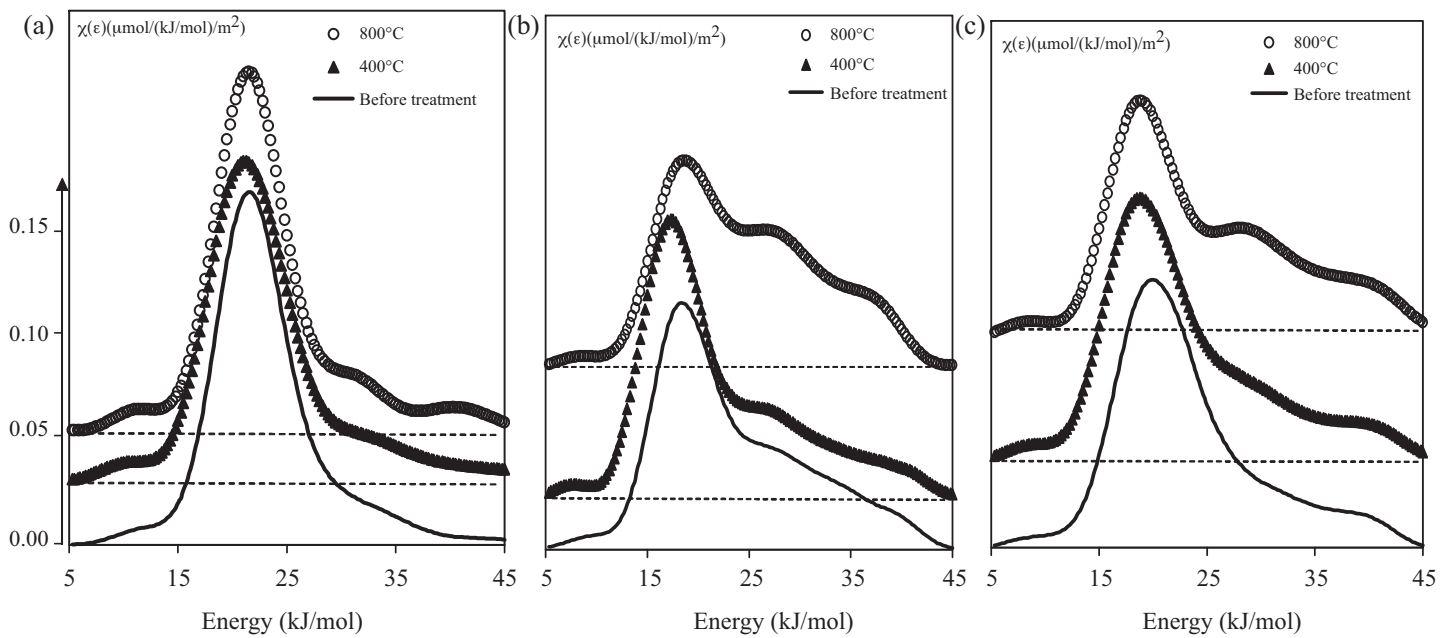

Fig. 9. Adsorption energy distribution functions of the n-octane (a) isopropanol (b) and 1,4-dioxan (c) probes of the initial and thermal treated attapulgite at $400{ }^{\circ} \mathrm{C}$ and $800^{\circ} \mathrm{C}$, measured respectively at $53^{\circ} \mathrm{C}, 43^{\circ} \mathrm{C}$ and $51^{\circ} \mathrm{C}$. 
which are more pronounced with polar probes. The weak shoulders observed with the octane, a probe sensitive to the morphology changes, indicate that the attapulgite morphology is affected by the melting of the fibers, while with polar probes, the two shoulders are attributed to the formation of the new phases as confirmed by X-ray diffraction.

\section{Conclusion}

After submitting attapulgite clay to a thermal treatment in $100-1000^{\circ} \mathrm{C}$ interval, two temperature ranges are distinguished from our study:

Below $500^{\circ} \mathrm{C}$, mass loss is mainly due to a departure of water molecules (related, zeolitic and crystalized water) and the fibrous morphology is preserved despite a rearrangement of the structure.

Above $500^{\circ} \mathrm{C}$, there is a coalescence of particles (sintering) reducing the porous volume network and consequently, the specific surface area. At high temperatures, new crystalline phases appear and the fibrous morphology is significantly affected due to the complete melting of the attapulgite fibers.

By IGC-ID, it is observed a decrease of the dispersive component of the surface energy and correlatively a decrease of the nanomorphological index emphasizing the appearance of a roughness of the carbonates surface.

The specific surface areas measured in IGC-FC reflect the approximation in the calculation of molecular areas of organic probes established from adsorption isotherms, generally, on non-porous solids. The differences on specific surface areas measured with nitrogen and organic probes on the raw solid and the solid treated until $400^{\circ} \mathrm{C}$, disappear on the attapulgite treated at $800^{\circ} \mathrm{C}$ which surface becomes flat.

The distribution functions also evolve with the thermal treatment indicating with octane modifications on the surface morphology and with isopropanol or 1,4-dioxan formation of new phases.

This study proves that inverse gas chromatography (IGC) is a convenient and powerful analysis method, in particular for the study of the evolution of physicochemical surface properties of a solid at a molecular scale under a thermal treatment, and it is a very complementary technique to other conventional techniques.

\section{Appendix A. Supplementary data}

Supplementary data associated with this article can be found, in the online version, at doi:10.1016/j.colsurfa.2012.02.015.

\section{References}

[1] H.H. Murray, Traditional and new applications for kaolin, smectite, and palygorskite: a general overview, Appl. Clay Sci. 17 (2000) 207-221.

[2] H.H. Murray, Applied clay mineralogy today and tomorrow, Clays Clay Miner. 34 (1999) 39-49.

[3] H.H. Murray, Overview - clay mineral applications, Appl. Clay Sci. 5 (1991) 379-395.

[4] J.D.D. Melo, T.C. De Carvalho Costa, A.M. De Medeiros, C.A. Paskocimas, Effects of thermal and chemical treatments on physical properties of kaolinite, Ceram. Int. 36 (2010) 33-38.

[5] A. Michot, D.S. Smith, S. Degot, C. Gault, Thermal conductivity and specific heat of kaolinite: evolution with thermal treatment, J. Eur. Ceram. Soc. 28 (2008) 2639-2644.

[6] D.L. Carroll, T.F. Kemp, T.J. Bastow, M.E. Smith, Solid-state NMR characterisation of the thermal transformation of a Hungarian white illite, Solid State Nucl. Magn. Reson. 28 (2005) 31-43.

[7] W.C. Pingxiao, W. Honghai, L. Rong, The microstructural study of thermal treatment montmorillonite from Heping, China, Spectrochim. Acta A 61 (2005) $3020-3025$

[8] Y. Laureiro, A. Jerez, F. Rouquérol, J. Rouquérol, Dehydration kinetics of Wyoming montmorillonite studied by controlled transformation rate thermal analysis, Thermochim. Acta 278 (1996) 165-173.

[9] J. Temuujin, K. Okada, K.J.D. MacKenzie, Ts. Jadambaa, The effect of water vapour atmospheres on the thermal transformation of kaolinite investigated by XRD, FTIR and solid state MAS NMR, J. Eur. Ceram. Soc. 19 (1999) $105-112$

[10] R.L. Frost, Z. Ding, Controlled rate thermal analysis and differential scanning calorimetry of sepiolites and palygorskites, Thermochim. Acta 397 (2003) 119-128.

[11] F. Gonzalez, C. Pesquera, I. Benito, Thermal investigation of acid-activated attapulgites: influence of isomorphic substitution in the octahedral sheet, Thermochim. Acta 194 (1992) 239-246.

[12] F. Gonzalez, C. Pesquera, C. Blanco, I. Benito, S. Mendioroz, J.A. Pajares, Structural and textural evolution under thermal treatment of natural and acid-activated Al-rich and Mg-rich palygorskites, Appl. Clay Sci. 5 (1990) 23-36.

[13] H. Balard, D. Maafa, A. Santini, J.B. Donnet, Study by inverse gas chromatography of the surface properties of milled graphites, J. Chromatogr. A 1198-1199 (2008) 173-180.

[14] M.P. Comard, R. Calvet, J.A. Dodds, H. Balard, Coupling of inverse gas chromatography at infinite dilution (IGC-ID) with a controlled modification of a solid surface, J. Chromatogr. A 969 (2002) 93-96.

[15] H. Kellou, B. Hamdi, E. Brendlé, T. Gottschalk-Gaudig, H. Barthel, H. Ridaoui, H. Balard, J.B. Donnet, Surface properties of dimethylsilylated silicas, assessed using IGC at finite concentration, Colloids Surf. A 327 (2008) 90-94.

[16] B. Hamdi, Z. Kessaïssia, J.B. Donnet, T.K. Wang, IGC characterization of surface energy and morphology of two natural fillers: kieselguhr and bentonite, Ann. Chim. Sci. Mater. 25 (2000) 481-494.

[17] X. Huang, B. Li, B. Shi, L. Li, Investigation on interfacial interaction of flame retarded and glass fiber reinforced PA66 composites by IGC/DSC/SEM, Polymer 49 (2008) 1049-1055

[18] A.B. Nastasovic, A.E. Onjia, Determination of glass temperature of polymers by inverse gas chromatography, J. Chromatogr. A 1195 (2008) 1-15.

[19] L. Boudriche, R. Calvet, B. Hamdi, H. Balard, Effect of acid treatment on surface properties evolution of attapulgite clay: an application of inverse gas chromatography, Colloids Surf. A 392 (2011) 45-54.

[20] E. Brendlé, E. Papirer, Suivi par chromatographie gazeuse inverse de la transformation de la goethite en hématite au cours d'un traitement thermique, J. Chim. Phys. 95 (1998) 1020-1051.

[21] B. Hamdi, Z. Kessaïssia, J.B. Donnet, T.K. Wang, Variation de l'énergie superficielle d'une bentonite par traitement chimique et thermique, Ann. Chim. Sci. Mater 24 (1999) 63-73.

[22] H. Balard, E. Brendlé, E. Papirer, Determination of the acid-base properties of solid surfaces using inverse gas chromatography: advantages and limitations, in: K. Mittal (Ed.), Acid-Base Interactions. Relevance to Adhesion Science and Technology, VSP, Utrecht, The Netherlands, 2000, pp. 299-316.

[23] J.R. Conder, C.L. Young, Physicochemical Measurements by Gas Chromatography, Wiley Interscience, New York, 1979, pp. 385-390.

[24] H. Balard, Estimation of the surface energetic heterogeneity of a solid by inverse gas chromatography, Langmuir 13 (1997) 1260-1269.

[25] G.M. Dorris, D.G. Gray, Adsorption spreading pressure and London force interactions of hydrocarbons on cellulose and wood fiber surfaces, J. Colloid Interface Sci. 71 (1979) 93-104.

[26] E. Brendlé, E. Papirer, A new topological index for molecular probes used in inverse gas chromatography for the surface nanorugosity evaluation. 1. Method of evaluation, J. Colloid Interface Sci. 194 (1997) 207-216.

[27] D.A. Mckeown, J.E. Post, E.S. Etz, Vibrational analysis of palygorskite and sepiolite, Clays Clay Miner. 50 (2002) 667-680.

[28] M. Rautureau, A. Mifsud, Etude par microscope électronique des différents états d'hydration de la sépiolite, Clay Miner. 12 (1977) 309-318.

[29] J. Khomari, A. Lemieux, Comparison of attapulgites from different sources using TG/DTG and FTIR, Thermochim. Acta 138 (1989) 97-105.

[30] A. Preisinger, Sepiolite and related compounds: its stability and application, Clays Clay Miner. 10 (1963) 365-371.

[31] B. Hamdi, Etude physico-chimique de la surface des diatomites, PhD thesis, University of Science and Technology Houari Boumediene (USTHB), 1998, pp. 43-64.

[32] W. Kuang, G.A. Facey, C. Detellier, Dehydration and rehydration of palygorskite and the influence of water on the nanopores, Clays Clay Miner. 52 (2004) 635-642.

[33] A. Mifsud, M. Rautureau, V. Fornes, Etude de l'eau dans la palygorskite à l'aide des analyses thermiques, Clay Miner. 13 (1978) 367-374.

[34] K. Traore, T.S. Kabre, P. Blanchart, Sintering of a clay from Burkina Faso by dilatometry influence of the applied load and the pre-sintering heating rate, Ceram. Int. 27 (2001) 875-882

[35] A. Khalfaoui, S. Kacim, M. Hajjaji, Sintering mechanism and ceramic phases of an illitic-chloritic raw clay, J. Eur. Ceram. Soc. 26 (2006) 161-167.

[36] P. Sidheswaran, Heat-induced structural modifications in palygorskite, Clay Res. 21 (2002) 27-39.

[37] N. Frini-Srasra, E. Srasra, Effect of heating on palygorskite and acid treated palygorskite properties, Surf. Eng. Appl. Electrochem. 44 (2008) 43-49.

[38] K. Kosuge, A. Ogata, Effect of $\mathrm{SiO}_{2}$ addition on thermal stability of mesoporous c-alumina composed of nanocrystallites, Micropor. Mesopor. Mater. 135 (2010) 60-66.

[39] T. Novakovic, N. Radic, B. Grbic, V. Dondur, M. Mitric, D. Randjelovic, D. Stoychev, P. Stefanov, The thermal stability of porous alumina/stainless steel catalyst support obtained by spray pyrolysis, Appl. Surf. Sci. 255 (2008) $3049-3055$. 
[40] C. Blanco, F. Gonzalez, C. Pesquera, I. Benito, Differences between one aluminic palygorskite and another magnesic by infrared spectroscopy, Spectrosc. Lett. 06 (1989) 659-673.

[41] M. Suárez, E. García-Romero, FTIR spectroscopic study of palygorskite: influence of the composition of the octahedral sheet, Appl. Clay Sci. 31 (2006) 154-163.
[42] E. Garcia-Romero, M. Suarez Barrios, M.A. Bustillo Revuelta, Characteristics of a Mg-palygorskite in Miocene rocks, Madrid basin (Spain), Clays Clay Miner. 52 (2004) 484-494.

[43] E. Mendelovici, Infrared study of attapulgite and $\mathrm{HCl}$ treated attapulgite, Clays Clay Miner. 21 (1973) 115-119. 